\title{
Elevated Temperatures Negatively Affect Olive Productive Cycle and Oil Quality
}

\author{
Giora Ben-Ari ${ }^{1, *}$, Iris Biton ${ }^{1}$, Yair Many ${ }^{1}$, Dvory Namdar ${ }^{1}$ and Alon Samach ${ }^{2}$ \\ 1 Volcani Center, Institute of Plant Sciences, ARO, Rishon LeZion 7528809, Israel; ivrb28@agri.gov.il (I.B.); \\ yairm@agri.gov.il (Y.M.); dvoran@agri.gov.il (D.N.) \\ 2 The Robert H. Smith Faculty of Agriculture, Food and Environment, The Robert H. Smith Institute of Plant \\ Sciences and Genetics in Agriculture, The Hebrew University of Jerusalem, Rehovot 76100, Israel; \\ samach@agri.huji.ac.il \\ * Correspondence: giora@agri.gov.il
}

check for updates

Citation: Ben-Ari, G.; Biton, I.; Many, Y.; Namdar, D.; Samach, A. Elevated Temperatures Negatively Affect Olive Productive Cycle and Oil Quality. Agronomy 2021, 11, 1492. https:// doi.org/10.3390/agronomy11081492

Academic Editor: Helder Fraga

Received: 3 July 2021

Accepted: 24 July 2021

Published: 27 July 2021

Publisher's Note: MDPI stays neutral with regard to jurisdictional claims in published maps and institutional affiliations.

Copyright: (c) 2021 by the authors. Licensee MDPI, Basel, Switzerland. This article is an open access article distributed under the terms and conditions of the Creative Commons Attribution (CC BY) license (https:// creativecommons.org/licenses/by/ $4.0 /)$

\begin{abstract}
Climate change, with elevated temperatures throughout the year, affects many stages of the reproductive growth and development of olives as well as oil quality at harvest. Although olive (Olea europaea L.) is well adapted to the environmental conditions of the Mediterranean Basin, agricultural techniques and breeding through selection programs will have to adapt to these climate change, threatening to worsen in the near future. Defining the pathways controlling high fruit productivity and oil quantity and quality, despite elevated temperatures and sub-optimal growing conditions, is important for coping with current and predicted climate changes. As breeding programs aiming to address these crucial changes may take several decades, an urgent need to designate specific olive cultivars that are more resistant to high temperatures emerges.
\end{abstract}

Keywords: Olea europaea; olive oil; heat stress; fruit production; high temperatures

\section{Introduction}

The picture emerging from a review of recent studies may be seen as foretelling agricultural techniques and future breeding and selection programs, designating specific olive cultivars that are more resistant to high temperatures. The olive (Olea europaea L.) is a crop well adapted to the environmental conditions prevailing in the Mediterranean Basin. Nevertheless, climate change occurring in the last decade and threatening to worsen in the future, with elevated temperatures throughout the year, affect many stages of the reproductive growth and development of olives as well as oil quality at harvest [1]. Defining the pathways controlling high fruit productivity and oil quantity and quality, despite elevated temperatures and sub-optimal growing conditions, is important for coping with current and predicted climate change.

Abiotic stresses are often interrelated in causing morphological, physiological, biochemical, and molecular changes that adversely affect plant growth and productivity and ultimately lead to reduced yield [2]. More specifically, the effect of high temperature environments on olive oil yield and quality is of increasing concern. The sexual reproductive phase in plants has been proven to be vulnerable to the negative effects of high temperatures stress [3]. In the Northern Hemisphere, olive trees go through flower induction during December and January ("winter"), Anthesis, pollination and fruit set during March to May ("spring"). The fruits accumulate oil from June to November [4]. Thermal conditions closely regulate all phases of the plant's life cycle [5]. Elevated temperatures may affect each of the above processes. Warm winters may affect flower induction; a warm spring may affect pollen grain and pistil viability, as cell division/expansion during fruit development may be affected by warm summers. An unusually warm summer may also affect oil accumulation and oil quality at harvest [1]. As global changes increase in intensity, studying these effects and processes in depth, defining sustainable varieties and finding 
ways to overcome temperature elevation becomes a worldwide concern. From the analysis conducted by the authors of the seasonal maximum and minimum temperatures measured by the Israel Meteorological Service over the last 20 years in Central Israel (ARO, Israel; $31^{\circ} 59^{\prime} 32.6^{\prime \prime} \mathrm{N} 34^{\circ} 49^{\prime} 03.8^{\prime \prime} \mathrm{E}$ ), an alarmingly steady trend of rising temperatures was derived. When mean temperature elevation was calculated for the different seasons (Dec-Jan defined as winter, Mar-Apr defined as spring, and Jul-Aug defined as summer), a linear trend of an almost $2{ }^{\circ} \mathrm{C}$ increase was demonstrated for summer, and linear trends of a $0.5^{\circ} \mathrm{C}$ increase for winter and spring were validated, over the last 20 years (Figure 1). Here, we will review each part of the developmental process of the olive fruit, in view of the biochemical processes behind them, and assess the effect of elevated temperatures on olive flowering, fruit development, oil accumulation, and oil quality.
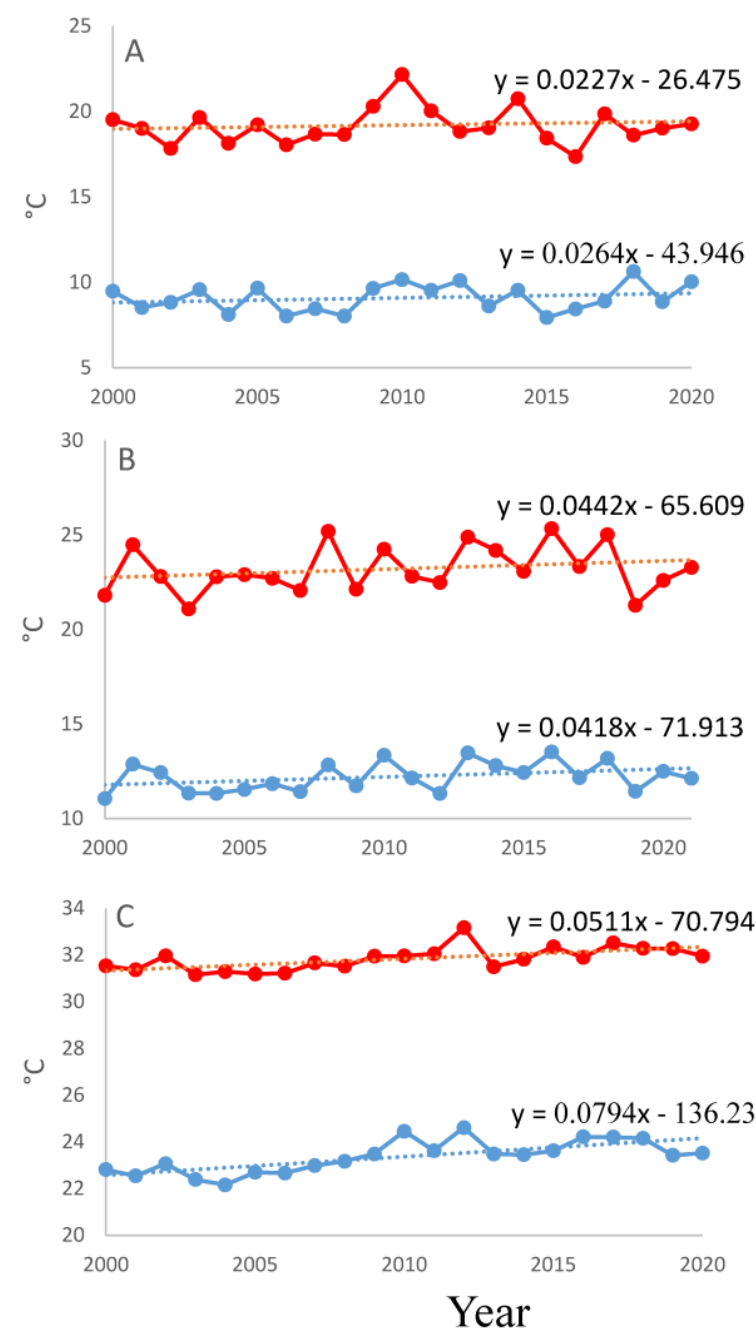

Figure 1. Seasonal average maximum/minimum temperatures measured over the last 2 decades in Central Israel (Bet Dagan; 31 $59^{\prime} 32.6^{\prime \prime}$ N $34^{\circ} 49^{\prime} 03.8^{\prime \prime}$ E). Data were collected by the Israel Meteorological Service. A trend of an increase by $0.5-2{ }^{\circ} \mathrm{C}$ was observed. Higher values reflect warmer summers, and lower values reflect warmer winters. (A) Winter (Dec-Jan); (B) spring (Mar-Apr); (C) summer (Jul-Aug). The red line presents the mean maximum temperatures; the blue line indicates the mean minimum temperatures; the dotted line shows a linear trend.

\section{Olive Reproductive Phase under Elevated Temperatures}

\subsection{Olive Flowering under Warmer Winters}

Similar to mango [6], litchi [7], and many other evergreen fruit trees, flower induction in olives requires cold winter temperatures [8,9]. If olive trees are exposed to naturally warm winters (tropics) or artificially warm winters (heated growth rooms), they will not 
form flowers [8]. The past literature suggested that flower induction in olive occurs in summer and that cold winter is necessary for dormancy break of differentiated inflorescences formed in lateral meristems of 1-year-old shoots [10]. The careful microscopic analysis of lateral meristems showed initial formation of an inflorescence meristem does not occur before late February [8]. While the molecular basis of flower induction in plants is once elusive, research in arabidopsis as well as other species such as rice and tomato clarifies the central and likely universal role of the FLOWERING LOCUS T (FT) protein in plant flowering [11].

Different seasonal environmental changes such as day length, temperature, or water availability can trigger flower induction of different plant species. Despite this variation in the environmental cause of flower induction, a common change associated with induction appears to be the accumulation of FT transcript in leaves [12]. This is followed by the movement of the FT protein to nearby meristems where it interacts with other proteins to initiate a switch in the fate of the vegetative leaf-forming meristem. In the absence of floral inhibitors that can inhibit FT function, the meristem will begin forming an inflorescence [13]. Once this mechanism is clarified, it becomes easier to examine the developmental stage as well as environmental cues leading to flower induction of different species, simply by following transcript levels of genes encoding proteins similar to FT.

In olives, FT transcripts accumulate in leaves in response to cold winter temperatures [8], thus clarifying the role of winter cold in flower induction, rather than release from winter dormancy, as previously proposed. What are the winter chilling requirements for olive flower induction and is there genetic variation in these chilling requirements among different cultivars? Clearly, the answer to the 2nd question is yes. Before going into details, two important points need to be addressed. Unlike arabidopsis, an annual plant with a single apical meristem that at some point goes through the floral transition, an olive tree contains many thousands of lateral meristems formed since last spring, and each one of these meristems can independently enter the floral transition or remain vegetative [8]. Thus, there is no chilling threshold that is achieved, and all lateral meristems will form flowers. The percent of lateral meristems that will go through the transition will increase, once winter temperatures have better met ideal conditions for olive flower induction [12].

The second important point to consider is that olive flower induction by winter chilling, as measured by the accumulation of FT transcripts in leaves during winter, is inhibited in trees that contain large amounts of fruit 2-4 months earlier [8]. Since the level of previous fruit load is varied, the level of inhibition is also varied. Thus, when winter temperatures meet the ideal conditions for olive flower induction, $80-90 \%$ of lateral meristems in trees with no previous fruit load may enter the flower transition. However, a significantly lower percent of these meristems will enter the transition in trees that hold an high fruit load [8]. When winter temperatures do not meet the ideal conditions for olive flower induction, perhaps only $10-30 \%$ of lateral meristems in trees with no previous fruit load will enter the flower transition, and trees with a previous heavy fruit load will not flower [8].

Olive cultivars vary in their chilling requirements [14] and likely their response to a certain level of fruit load. Thus, two varieties with the same level of fruit load may flower differently after a certain winter, and the cause of this difference may not be different chilling requirements but differences in response to a certain fruit load. Studying the net chilling requirements of different olive cultivars requires removing all flowers/fruitlets in the previous spring. We suggest that studying variation in the response to a certain level of fruit load would be best performed under ideal winter chilling conditions.

What are ideal winter temperature conditions for olive flower induction? "Barnea" trees grown in pots, with no previous fruit load, and exposed from late November onwards for $\sim 90$ days to a $16 / 10{ }^{\circ} \mathrm{C}$ day/night temperature regime form inflorescences in $\sim 85 \%$ of lateral meristems [8]. "Manzanilo" potted trees are exposed to different conditions [15]. Those exposed to 113 days of constant $13{ }^{\circ} \mathrm{C}$ form inflorescences in $50-85 \%$ of lateral meristems [15]. Those exposed to 113 days at $16^{\circ} \mathrm{C}$ form inflorescences in $37 \%$ of lateral meristems [15]. Those grown in glasshouses with a minimum temperature of $16{ }^{\circ} \mathrm{C}$ do 
not flower. Under constant conditions, exposure to $10^{\circ} \mathrm{C}$ is as effective as exposure to $13{ }^{\circ} \mathrm{C}$. However, the exposure to a lower temperature of $7^{\circ} \mathrm{C}$ appears less effective, and the exposure to a constant temperature of $4{ }^{\circ} \mathrm{C}$ does not induce flowering at all [15]. Based on these results, it appears that temperatures above $7^{\circ} \mathrm{C}$ and below $16^{\circ} \mathrm{C}$ may be optimal for olive flowering. A recently used model [5,16] applied for calculating accumulated chilling hours during the winter period suggests counting hours below $7.2{ }^{\circ} \mathrm{C}$, similar to the model applied on dormancy release in peach. Such a model does not fit the results on olive trees presented above. Others have suggested a range of $0-16^{\circ} \mathrm{C}$ for olive induction with an optimal temperature of $7.3^{\circ} \mathrm{C}$ [17]. Raising January temperatures by $4{ }^{\circ} \mathrm{C}$ using temperature-controlled open-top chambers in Cordoba, Spain [18] increases the average monthly temperature to 11,15 , and $12{ }^{\circ} \mathrm{C}$ during three consecutive years has no noticeable effect on flowering levels, compared to that of trees that are not warmed up. Still, flowering is lowest in the year with higher winter temperatures [18].

During natural winter conditions, some days may be much warmer than the average. Whether these warmer episodes can "erase" the effect of previously accumulated chilling hours is questioned. The model presented by De Melo-Abreu supports the ability of temperatures above $16{ }^{\circ} \mathrm{C}$ to erase chilling hours, with temperatures above $20^{\circ} \mathrm{C}$ having an optimal erasing effect [17]. This model is very helpful, but it clearly requires optimization so that growers can better predict the level of flowering expected in a new growing region based on temperature data from previous years. Such a predictive model can also foresee the future of successfully growing olives in regions where winters are becoming warmer. In Los Tomilos, Canary Islands, minimum temperatures during the winter period are quite high, but "Picual" and "Arbequina" cultivars still flower at much lower levels and in several waves, extending the period of anthesis, with first flowering occuring before similar cultivars in colder regions [19]. In less extreme climates, the solution may be choosing cultivars with lower chilling requirements. For example, when comparing the "Ascolano" and "Mission" cultivars, it appears that the chilling requirements of "Mission" are much lower [14]. When comparing "Arbequina" to "Leccino" and "Frantoio", the chilling requirements of "Arbequina" are much lower [20].

The time interval between inflorescence initiation and anthesis is also temperaturedependent. Warmer environments can shorten this period, and it is expected that global warming will advance olive anthesis dates for 17 days by the end of this century [16].

Such forecasting models are essential for adapting appropriate agro-technological practices to face the predicted climate change [19]. It seems that a more sophisticated and complex model combining an array of meteorological and physiological parameters is required for assessing climate change impacts. The simulation of the response of agricultural systems to predicted climate conditions is crucial for overcoming the high degree of uncertainty inherent in such studies [21]. Among cultivars grown at a single location, dates of anthesis differ by 20-24 days; for the same cultivar grown in different locations, dates of anthesis differ by up to 14 days [16]. A prolonged period of anthesis, caused under reduced chilling conditions $[5,18,19]$, can result in asynchronous ripening, i.e., fruits ripen over a wide time span and at harvest only part of the crop is fully ripe, while many fruits remain immature and others are harvested when over-ripe [8]. This, in turn, leads to a reduction in oil yield and quality [8].

\subsection{Olive Fruit Set under Warmer Spring Temperatures}

In general, olives do not self-pollinate, as they have a homomorphic sporophytic di-allelic self-incompatibility (DSI) system [22]. This system prevents self-fertilization and thus regulates compatibility between cultivars, so that cultivars bearing similar genetic characteristics are incompatible. Efficient pollination and fertilization depend on many factors, such as the duration of stigma receptivity and morphology, pollen grain sustainability, and pollen tube development. Cuevas and Polito [23] suggested that as pollen is produced in excess, even when affected by extreme heat spells, the reduction of pollen production is insignificant and does not affect germination and/or fruit yield. Another significant 
parameter is the presence of pollen from a compatible cultivar growing in the same or neighboring orchard, which blooms simultaneously [22,24-28]. Early-spring (April-May) temperatures can significantly affect the fruit set stage that is harmed by the premature onset of the flowering period [21]. Simulation models based on monitored flowering experiments depict a shift in the flowering period in regions or years when warm springs occur. Flowering precedes the normal period by approximately 10 days, when the temperature increases by $4-5{ }^{\circ} \mathrm{C}[17,29-31]$. A related observation was reported by Lorite et al. [21], who noted that olive cultivars which naturally flower earlier are less impacted by elevated temperatures. This, in turn, will also affect the fruit set stage [18].

Benlloch-González et al. [18] showed that the fruit set fails when olive trees are exposed to $4{ }^{\circ} \mathrm{C}$ above their ambient temperature. Under these conditions, several effects are observed such as hindrance in floral differentiation, postponed flowering dates, prolongation of the flowering period, and an increase of pistil abortion. This leads to a reduction in fruit set [18].

Poor fruit sets are recorded in olives, when high temperatures occur during the blooming period [32]. The constant temperature of $30{ }^{\circ} \mathrm{C}\left(+5{ }^{\circ} \mathrm{C}\right.$ above the ambient temperature) inhibits the fruit set and reduces pollen germination, although pollen tube growth still occurs. Pollen tubes penetrate the ovule in $47 \%$ of the cases. The lack of growth of both functional ovules and ovaries, despite pollen tube development and partial ovule penetration, suggests that zygote formation or endosperm development is negatively affected by the heat stress [32]. Note that low temperatures also affect the fruit set. At $20{ }^{\circ} \mathrm{C}\left(-5^{\circ} \mathrm{C}\right.$ below the favorable temperature), pollen tube growth is stalled, resulting in reduced fertilization [32].

Pollen viability is commonly determined based on three parameters-pollen germination, pollen tube growth, and fertilization percentage. Negative change is recorded in all three parameters of pollen viability, when the "Oblica" olive cultivar is exposed to elevated temperatures [33]. Interestingly (and counter intuitively), exposure to higher temperatures two days before the start of flowering, actually enhances pollen germination and shortens the duration of the flowering period by one day. This was observed in "Oblica" trees [33,34] as well as in "Leccino", "Levantinka", and "Pendolino" varieties [34]. Optimum temperature for pollen germination is also genotype-dependent. The fertilization competence of four pollen donor cultivars ("Leccino", "Levantinka", "Oblica", and "Pendolino") were compared after $24 \mathrm{~h}$ at different temperatures. In general, increasing temperatures from 15 to $30{ }^{\circ} \mathrm{C}$ has a positive effect on pollen tube growth and germination rates. At $35^{\circ} \mathrm{C}$, on the other hand, the trend is reversed, as pollen tube growth and germination rates are significantly lowered. This reduction was genotype-dependent. "Levantinka" and "Pendolino" show higher resistance than "Leccino" and "Oblica" to temperatures higher than the optimal [34]. Other olive cultivars- "Koroneiki", "Kalamata", "Mastoidis", and "Amigdalolia" were also tested to assess the effect of temperature on pollen germination and tube growth and to determine the optimal germination temperatures for each cultivar [35]. Raising the temperatures from 20 to $30{ }^{\circ} \mathrm{C}$, positively affects pollen germination in all cultivars studied, achieving a 52\% increase (for "Mastoidis") in pollen germination and pollen tube length. All the cultivars studied benefit from elevated temperatures up to the optimal temperature of $30^{\circ} \mathrm{C}$. However, when temperatures rise to $35^{\circ} \mathrm{C}$ and then to $40^{\circ} \mathrm{C}$, a strong genotype-differentiated response is demonstrated, with "Koroneiki" and "Kalamata" acknowledged to be more tolerant than "Mastoidis" and "Amigdalolia" [35].

Other related topics, such as irrigation as a mean to defeat elevated temperatures and the effect of elevated temperatures on olive pests (such as Verticillium, anthracnose, Bactrocera oleae), are not within the scope of this review and thus were not discussed here, although they merit a careful consideration [36-39]. It is recognized that excess irrigation during fruit development results in lower phenolic concentrations, possibly due to changes in the biosynthetic and catabolic polyphenol pathways in the olive fruit [40-44]. In this respect, a genotype variability was noted. For example, the "Souri" cultivar showed no significant 
decrease in polyphenol level under high temperature conditions, thus suggesting that some cultivars may be relatively more tolerant to high temperatures [4].

\subsection{Fruit Development under Warmer Summers}

Extreme summer temperatures can impair intermolecular interactions needed for proper growth of olive fruits [45]. Exposure of plants to high temperatures affects different vegetative parameters such as sunburn causal, leaf abscission, and growth inhibition [46,47], as well as reduction of starch, protein, and oil content $[48,49]$. Plants exposed to temperatures above their optimal growing temperatures exhibit cellular and metabolic survival responses [2,50-53]. The type and degree of damage caused to crops by high temperatures depend on the growth stage at the time when the exposure occurs and the severity of the stress. The reproductive phase is more sensitive to high temperatures than other phases, and this may lead to yield reduction [54].

As in other drupes, olive fruit development is characterized by a double sigmoid growth curve for fruit size and weight $[55,56]$. This means that the growth pace is accelerated, then holds steady for a varied length of time and then accelerated again until the fruit peaks at maximal size. The first sigmoidal increase in size is attributed to cell division, while the second increase is attributed to cell expansion. Both cell division and cell expansion contribute to initial mesocarp growth [57]. Therefore, the difference in fruit size between cultivars is initially dictated by cell division rate. Later, fruit growth is determined by the increase in cell size [58]. Several studies have examined the effect of high temperatures on olive fruit weight (over different time spans). Studies carried out over long periods of time and over a wide range of temperatures showed that dry fruit weight is not affected by average temperatures within a range of $16-25^{\circ} \mathrm{C}$ but was reduced with further increases in temperature [59,60]. Our previous work [4] showed that under warmer summers the double sigmoid growth curve is flattened and fruit yield and oil quality are reduced (Figure 2).
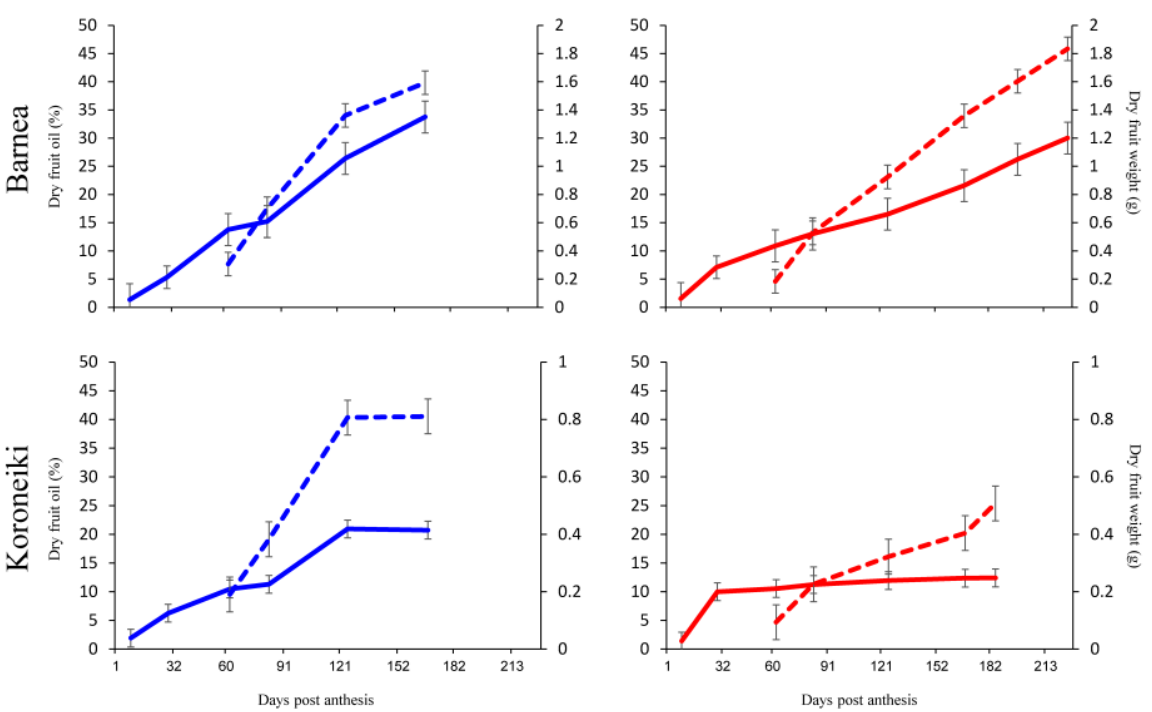

Figure 2. Double sigmoid growth curve of dry fruit oil (\%) occurring in two cultivars grown under mild summers (on the left hand; in blue) and flattened in the same cultivars when grown under extreme hot summer (on the right hand; in red). The full lines indicate fruit weight; the dashed lines represent the oil percent. The figures were prepared based on previous published data by the co-authors [4].

It has been suggested that for tomatoes, high temperature during fruit development has a greater effect on cell division than on cell expansion [61,62]. Researchers found that in olives, as in other drupes, both cell division and cell expansion contribute to mesocarpal growth at early stages of fruit development $[57,58]$. In contrast to this observation, the 
heat-tolerant "Barnea" cultivar delays mesocarpal cell division until the arrival of milder weather in following months [4]. Nissim et al. [4] suggested that the main effect of high temperatures on olive fruit weight is through the repression of both cell expansion and cell division.

The term "heat" or "high temperatures" must be more carefully defined. Does the term refer to the maximum temperature at mid-day, the maximum temperature at night, or the amplitude of the measured temperatures over $24 \mathrm{~h}$ ? Similarly, the injury to the fruit must be defined and quantified. Several studies have investigated the effects of high temperatures on fruit size. For example, the maximum temperatures measured during the night were proved to affect the size of tomatoes [61]. On the other hand, Nissim et al. [4] who studied the three parameters of heat - the maximum day temperature, the maximum night temperature, and 24-h-period temperature amplitude-concluded that the maximum day temperature is the most relevant heat component of the three in inhibiting olive fruit growth.

For the "Arauco" cultivar, $25^{\circ} \mathrm{C}$ is defined as the ambient mean temperature optimal for olive fruit production [63]. Dry fruit weight measured at several locations in the province of La Rioja, Argentina shows a tendency to decrease with increasing mean temperature [63]. This effect appears at temperatures above the range of $16-25^{\circ} \mathrm{C}$. At these temperatures, dry fruit weight decreases at a rate of $0.08 \mathrm{~g}$ for each additional $1{ }^{\circ} \mathrm{C}$ [59]. In general, high temperatures during fruit development affect three important traitsfruit weight, oil concentration, and oil quality. Various cultivars demonstrate different levels of heat intolerance. The final dry fruit weight at harvest of the "Barnea" cultivar is affected by a high temperature environment, whereas the "Koroneiki", "Picholine", "Souri", and "Coratina" cultivars exhibit decreases in dry fruit weight at harvest under higher temperatures by $0.2,0.2,0.4$, and $1 \mathrm{~g}$ per fruit, respectively.

\section{Olive Oil Production under Elevated Temperatures}

\subsection{Oil Accumulation under Warmer Summers}

Oil accumulation in olive fruits is known to begin in June and to last until midOctober. It then slows down during November-December $[4,64]$. The total period of drupe development from flowering until maturation lasts 18-20 weeks. During this period, the drupe passes through four developmental stages: 0-2 weeks after flowering (WAF) is characterised by ovary growth through cell division. From 2-6 WAF, the drupe grows by cell division. At 6-16 WAF, cells continue to expand, as lipids are stored in oil bodies in the mesocarpal cells. The last stage is 16-20 WAF, when epicarp colouration begins and the fruit peel begins to turn purple due to intense anthocyanin deposition in the cell vacuoles [55,65]. At harvest, oil droplets occupy about $80 \%$ of the cell volume $[4,66,67]$.

Oil concentration shows an insignificant linear decrease of $1.1 \%$ per degree, as temperatures increased from 16 to $32^{\circ} \mathrm{C}$. Another increase of $7^{\circ} \mathrm{C}$ has a permanent negative effect on oil concentration at final harvest, particularly when the exposure to high temperature occurs at the beginning of oil accumulation [59].

Elevated temperatures affect oil production [68]. This negative effect on oil production in plants is felt in different ways; for example, elevated temperatures reduce oil production in sunflower hybrids by 6\% [69], but do not influence oil production in corn [70]. Olive oil concentrations, however, are even more complex, as the effect of higher temperatures is genotype-dependent [71]. The final oil concentrations of "Barnea", "Picholine", and "Coratina" do not change even when grown at almost $50{ }^{\circ} \mathrm{C}$, while the oil concentrations of "Koroneiki" and "Souri" decrease in average by $2 \%$ per degree of increased maximum daily temperature [4]. The oil concentration of the "Arauco" cultivar decreases by $1.1 \%$ per degree of increased temperature [59]. "Coratina" and "Arbequina" trees reduce oil concentration by $5 \%$ on average as a response to warmer environments. This was demonstrated for other cultivars as well [60].

García-Inza et al. [51] showed that besides the mean maximum temperature, other heat temperature parameters should be also evaluated, i.e., mean minimum temperature 
and mean thermal amplitude. Thermal amplitude is the difference between minimal (night) temperatures and maximal (day) daily oscillation in temperatures. The thermal amplitude was found to have an inverse association with oil accumulation and a positive linear association with oil quality [63]. This means that as the gap between the maximum and minimum mean temperatures gets larger, oil yield reduces but oil quality is enhanced.

García-Inza et al. [59] found that high temperatures during oil accumulation negatively affect olive oil yield and quality in warm regions, particularly if high-temperature events occur early during the fruit development process, i.e., affecting cell division. However, our preliminary results suggested different findings. We found that fruit development is affected by elevated temperature regardless of the time of occurrence during this process, while oil accumulation and quality are most affect specifically when the high-temperature events occur after pit hardening (unpublished data). Fruit weights and oil accumulations in "Koroneiki", "Coratina", and "Picholine" are much lower when grown under high temperatures compared to those of the same cultuivars grown under milder temperatures. On the other hand, the "Barnea" cultivar exhibits greater tolerance for high temperatures; thus, final fruit weight and oil percentage are similar in olive trees grown under either high or moderate temperature conditions [50]. Final oil content is also cultivar-dependent, as "Barnea", "Coratina", and "Picholine" show no affect when exposed to high temperatures. The "Koroneiki" and "Souri" cultivars, under similar conditions, show drops in oil content by $15 \%$ and $8 \%$, respectively. As for oil quality, the "Souri" cultivar shows higher tolerance to high temperatures than any of the other cultivars studied [4].

Nissin et al. [72] demonstrated the genetic mechanism controlling this genotypedependent tolerance. The degree of induction of heat shock proteins as a response to high temperatures is cultivar-dependent. The heat-resistant "Barnea" cultivar shows a larger degree of induction than the heat-sensitive "Souri" variant. Moreover, different genes involved in olive oil biosynthesis are repressed when exposed to heat; the genes show cultivar-dependent expression patterns according to their heat tolerance characteristics [72]. Using these molecular observations, the identification or development of more heat-resistant cultivars maintaining high yield and quality of oil is critical for a future characterized by global warming.

\subsection{Olive Oil Quality under Warmer Summers}

Oil quality, which can be measured by high oleic acid $\left(\mathrm{C}_{18: 1}\right)$ levels and/or low linoleic acid $\left(\mathrm{C}_{18: 2}\right)$ levels, shows a positive correlation with oleic acid levels and negative association with linoleic acid levels. In other words, the high-temperature amplitude has a positive effect on oil quality [63]. No significant association with the mean maximum temperature was found, which is a crucial point in defining the relevant temperature correlated with those changes. The minimum temperature, on the other hand, has a strong negative effect on oil quality [63], suggesting that the attainment of high-quality oil requires somewhat elevated threshold temperatures. These results [63] suggest that recording spells of high temperatures alone does not reflect the complex conditions affecting fruit yield, oil content, and oil quality in olives. The minimum temperature and the thermal amplitude must also be considered.

Temperature is undoubtedly an important factor contributing to variations in oil quality, particularly the temperatures prevailing from the time of stone hardening until the beginning of fruit colour change, i.e., July till October [73]. Oil quality seems to be the parameter most acutely affected by high temperatures. Olive oil quality is determined mainly by the free acidity, expressed in $\%$ and defined by the relative concentration of the monounsaturated fatty acid named oleic acid $\left(C_{18: 1}\right)$, which has a clear impact on the quality of olive oil. The chemical composition of olive oil is composed mainly of oleic acid, which comprises up to $83 \%$ of the total, with residual amounts of palmitic acid $\left(\mathrm{C}_{16: 0}\right.$; 7.5-20\%), linoleic acid $\left(\mathrm{C}_{18: 2} ; 3.5-21 \%\right)$, stearic acid $\left(\mathrm{C}_{18: 0}\right)$, and linolenic acid $\left(\mathrm{C}_{18: 3}\right)$ [73,74]. The oleic acid concentration decreases by $0.7 \%$ per degree, as temperatures increase from 16 to $32{ }^{\circ} \mathrm{C}$ [63]. Commentary, the evaluation of oil quality is also based on several accepted 
physicochemical and sensory parameters, such as organoleptic quality and phenolic and volatile compounds, as defined by the International Olive Council (IOC) [75].

During summer, temperatures can reach up to $46^{\circ} \mathrm{C}$. Such high temperatures during oil accumulation can certainly decrease fruit size, oil yield, and oil quality. Oil quality defined by fatty acid composition (i.e., \% oleic acid) and polyphenol levels is lower when grown in high temperatures for any of the studied cultivars. However, heat tolerance is genotype-dependent [4], where some cultivars' oil qualities are affected more than others. Thus, the oil qualities of the "Barnea" and "Picholine" cultivars are severely affected by high temperatures, while the "Souri" type is recognized as more heat-tolerant.

The chemical parameters used to determine olive oil quality are the total polyphenol profile and fatty acid composition. Polyphenol levels decrease during fruit development $[76,77]$, positively corresponding with water restrictions [78,79]. Elevated temperatures lead to a dramatic decrease of up to $65 \%$ in the total polyphenol content of most analyzed cultivars [4].

As mentioned above, the second criteria of oil quality is the fatty acid composition, mainly the oleic acid content. In sunflower oil, for example, heat stress causes an increase in oleic acid content and a reduction of linoleic acid [69]. In olive, high temperatures cause a decrease in oleic acid concentration and increases of linoleic and palmitic acids $[59,80]$. The different mechanisms, leading to opposite outcomes, may be partly explained by the genes involved in the oil biosynthesis pathway as seen through their levels of expression [81]. The reaction begins in the cytosol and advances to the plastid and terminates at the endoplasmic reticulum. Tracking the expression pattern of genes involved in the oil biosynthesis in olive fruit reveals that oleic acid is produced when the fatty acid desaturases (FAD) are activated. In high-quality oil, oleic acid is produced through fatty acid desaturases, while FAD2 synthases remain inactive. However, when the tree is subjected to heat stress, FAD2 synthases are activated and linoleic acid is produced. As linoleic acid is synthesized from oleic acid, the level of oleic acid will decrease and levels of linoleic acid will rise [72].

The influence of temperatures during the growing season on fatty acid composition of 188 Italian cultivars was studied between 2001 and 2005. Significantly lower concentrations of oleic acid and higher palmitic and linoleic acids levels were found in the warmest year of the study (2003) compared to in the coolest year (2005) [73]. Standard levels of fatty acid composition in olive oil determined by the IOC state that olive oil must contain 55-83\% oleic acid and 3.5-21\% linoleic acid. The oils obtained from olives grown in extreme heat conditions contain up to $23 \%$ linoleic acid and only $52 \%$ oleic acid, neither of which meets the standards of the IOC [73].

Genotype variability was demonstrated in the present study. Out of the five cultivars analyzed, the "Souri" cultivar showed the smallest decrease in oleic acid $(<4 \%)$ and the smallest increase in linoleic acid (1.5\%) under elevated temperatures [4]. Taken with total polyphenol levels, this suggests that some cultivars may be more resistant to high temperature environments than the others. As global warming spreads, this information becomes extremely important.

The early harvesting of olives is an increasingly widespread trend in Mediterranean countries that aims to increase the quality of oils by using less mature fruits over the expenses of oil amounts. However, early harvesting in countries that have very warm autumns means harvesting and processing during higher temperatures, which may in turn affect the quality of oil [82-84]. The internal temperature of the fruits at the time of processing and the temperatures maintained during the milling and malaxation steps on olive oil quality should be considered.

\section{Strategies to Olive Crop Improvement for High-Temperature Tolerance}

In order to address the continued global warming and its effect on olive oil yield and quality, suitable cultivars must be identified. Olive trees growing in regions with extreme conditions characterized by high summer temperatures should be studied. Nissin et al. [50] compared fruit yield and oil quality of trees growing in warmer summer regions with those 
of the same trees/cultivars growing in a region of relatively mild summers. Their study found that the effects of a high temperature environment are genotype-dependent. Similar conclusions have been extrapolated for heat resistance during the period of activation of the the fruit set throughout years with unusually warm spring weather [34,35] and during winters when flowering induction is set [8]. Clearly, heat-resistant genotypes should be selected for breeding.

The abovementioned results suggest that different olive cultivars adopt different mechanisms to successfully endure high temperatures. The first step, therefore, in adapting olive culture to changing climatic conditions would be to scan a wide range of cultivars growing under extreme heat conditions and study their ability to respond effectively to these conditions. Elucidating the mechanisms enhancing these abilities may open a way toward the development of new olive cultivars adapted to high temperature conditions.

In support of the genetic approach to facing the challenge of climate change, new agro-technical solutions that will enable reducing the temperature during critically hot days or periods should be actively sought. For this, systematic research should be conducted in attempt to compile a comprehensive set of data regarding the ambient temperatures for each cultivar and the intolerance threshold to which each cultivar can no longer respond. Complimentary critical temperatures-a cold quotient requirement model for winter as well as a "critical heat damage model" for hot springs and extreme summers-are also necessary. Some initial attempts to use omics methods for olive and other oil fruits were carried out [85-88]. Recent advances in bioinformatics and analytical tools, i.e., nextgeneration sequencing and mass spectrometry, may be very helpful for revealing and tracking the olive ripening mechanism. Genomics-based high-dimensional datasets, such as transcriptomics, proteomics, and metabolomics, provide an in-depth understanding of the molecular-specific processes regulating olive fruit development and ripening [85]. These post-genomics tools are well-established technologies and have been used as phenotyping tools to elucidate the mechanisms involved in fruit ripening and fatty acid synthesis, all of which promise to facilitate and speed up the improvement of oil quality and olive productivity [86]. The incomplete sequence of olive reference genome is the most obvious obstacle currently preventing from this task being achieved [85].

\section{Conclusions and Future Prospects}

The effect of high temperatures is the dominant suppressor of fruit sets among the cultivars of possible abiotic stresses [60]. Comparing the effect of heat to that of drought demonstrates the importance of its effects. Deficient irrigation reduces tree growth but does not affect return bloom or fruit yield even after a reduction of $50 \%$ [89]. This is not the case with high temperatures. As seen above, even $3-4{ }^{\circ} \mathrm{C}$ above ambient temperature significantly damages fruit yield, oil amount, and oil quality. The Mediterranean Basin is one of the regions that is expected to be affected most by future climate change.

Projected future (2070-2100) annual and seasonal average changes in mean air temperature were calculated for the period of 1970 to 2000 and used in future climate model projections [90]. Future surface mean air temperatures of the larger Mediterranean Basin was calculated to increase by up to $7^{\circ} \mathrm{C}$ over the next 80 years, i.e., by almost $0.9^{\circ} \mathrm{C}$ per decade, and the intensity of high temperatures events will be also likely to increase in the future [90]. These projected trends (Figure 3), together with the important role of olive oil in human nutrition, demonstrate the need for meeting the challenge of the effect of climate change on the continued production of high-quality olive oil. Identifying more resilient cultivars of olives is today's major goal of olive geneticists. This review has demonstrated that most types and levels of the olive's response to high temperatures are genotype-dependent. Identifying the threshold temperatures for the optimal olive production of different olive genotypes and how temperature variation affects olive physiological, biochemical, and molecular mechanisms is another aspect that we consider crucial. 

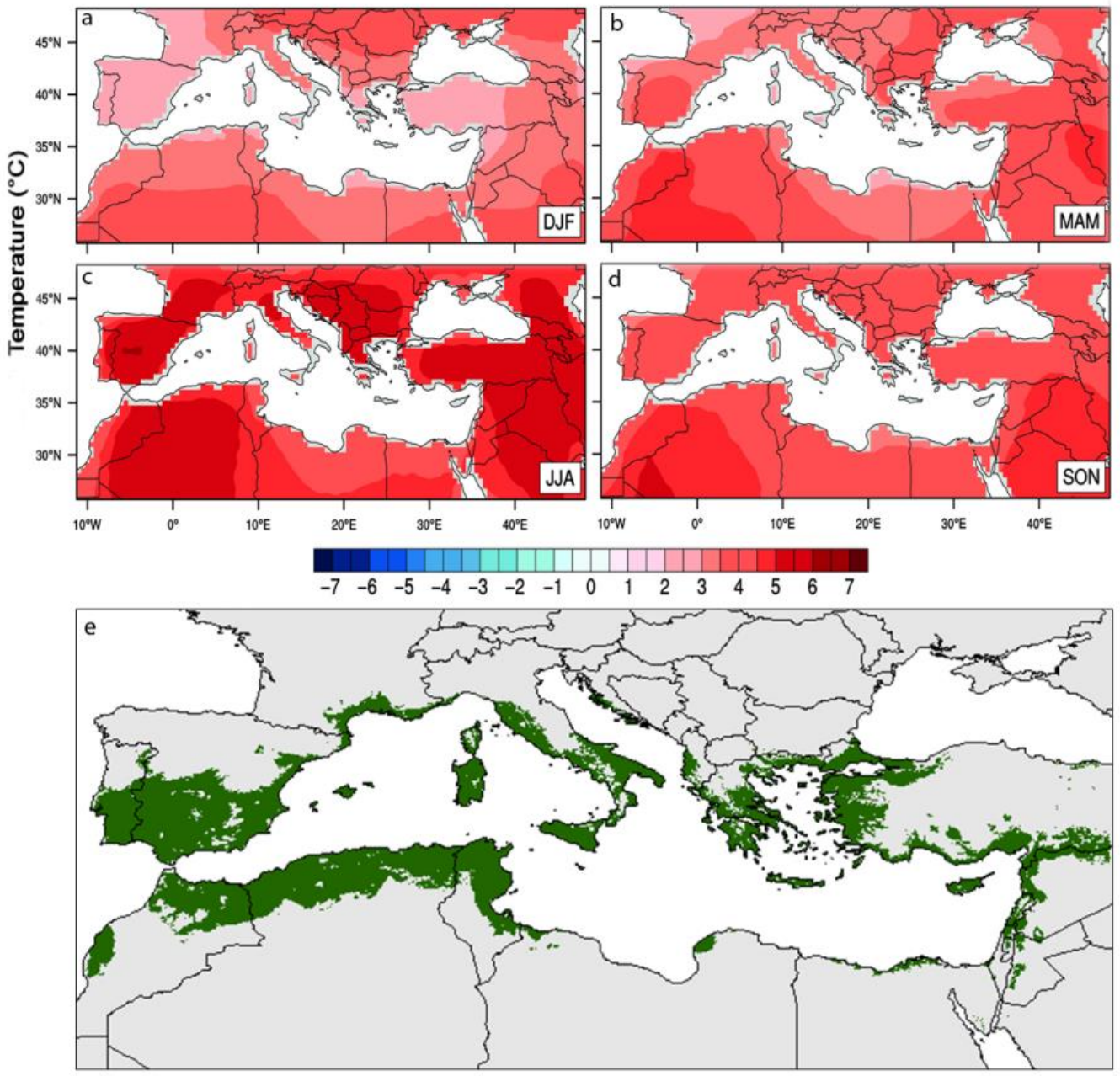

Figure 3. Estimated future changes in mean air temperature around the Mediterranean Basin during the future period of 2070-2100. Expected temperatures were calculated based on retrieved data from 1970 to 2000 and A2 future climate model projections [90]. (a) winter temperatures (DJF: DecemberJanuary-February); (b) spring temperatures (MAM: March-April-May); (c) summer temperatures (JJA: June-July-August); (d) spring temperatures (SON: September-October-November). Figure were prepared based on the work conducted by Oztürk et al., with the consent of the authors; (e) distribution of olive culture around the Great Mediterranean Basin. Taken from https://pin.it/ 3YG0UaF (accessed on 26 July 2021).

The oil of each olive cultivar is characterized by its own genetically determined balance of fatty acids, and each is affected differently by changing seasonal temperatures. The four main fatty acids of olive oil, arranged in the order of their biosynthetic pathway, are palmitic $\left(C_{16: 0}\right)$, oleic acid $\left(C_{18: 1}\right)$, linoleic $\left(C_{18: 2}\right)$, and linolenic $\left(C_{18: 3}\right)$ acids. Any inhibition or promotion of a reaction in the pathway will affect the balance of these fatty acids. For example, the degradation of oleic acid may be compensated for by an increase in any of the other three fatty acids. The remaining concentration of oleic acid is characteristic of each genotype and determines the heat resistance of a particular cultivar [73]. Thus, each of the resistant cultivars may be identified, and its degree of heat sensitivity/resistance is characterized.

To achieve this goal, more basic data are needed to complete the sensitivity map (Figure 4 and references therein), which can be achieved by screening the cultivar collections managed in different parts of the world today. We mapped the current published data regarding sensitivity/resilience of different cultivars studied and sketched the status of sustainability (Figure 4). This chart should be expanded, and the sensitivity level of 
many more cultivars should be evaluated. Following that, a more in-depth genetic study should be carried out to identify genes controlling the sensitivities/resistances of different cultivars with each of the different parameters we discussed, i.e., flowering, fruit set, fruit development, oil accumulation, and oil quality. This accumulative data should be carefully screened and used in future breeding programs designed to address the increasing challenge of global warming, especially as predicted for the Greater Mediterranean Basin.

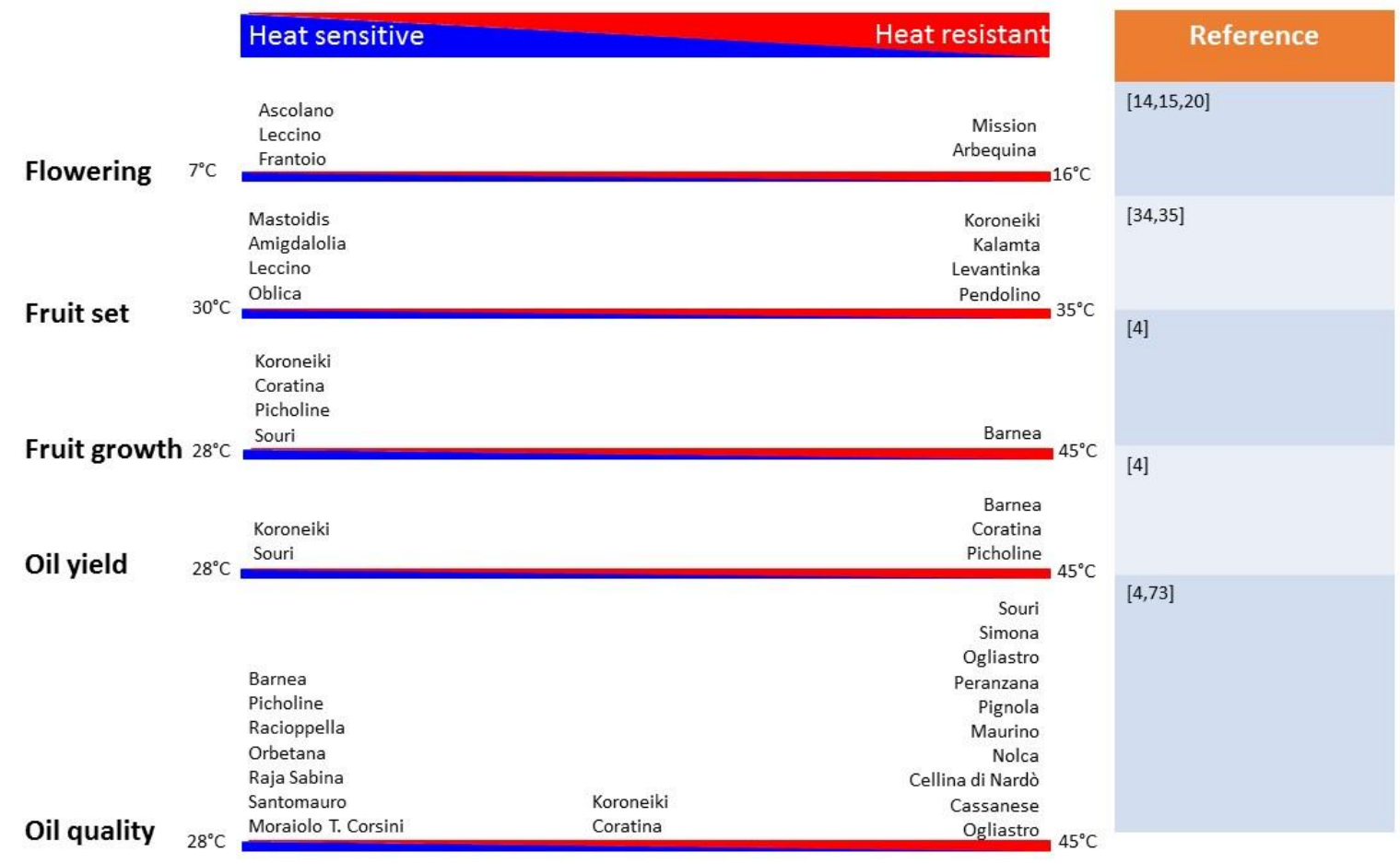

Figure 4. Sensitivity response map of different oil cultivars to elevated temperature environments during various developmental stages of olive fruit.

Author Contributions: I.B., Y.M., D.N., A.S. and G.B.-A. gathered the data and wrote the manuscript. All authors have read and agreed to the published version of the manuscript.

Funding: N/A.

Acknowledgments: We thank Yehuda Ben-Ari for valuable assistance in writing and editing this paper.

Conflicts of Interest: The authors declare no conflict of interest.

\section{References}

1. Fraga, H.; Moriondo, M.; Leolini, L.; Santos, J.A. Mediterranean olive orchards under climate change: A review of future impacts and adaptation strategies. Agronomy 2021, 11, 56. [CrossRef]

2. Bita, C.; Gerats, T. Plant tolerance to high temperature in a changing environment: Scientific fundamentals and production of heat stress-tolerant crops. Front. Plant Sci. 2013, 4, 273. [CrossRef] [PubMed]

3. Hedhly, A.; Hormaza, J.I.; Herrero, M. Global warming and sexual plant reproduction. Trends Plant Sci. 2009, 14, 30-36. [CrossRef] [PubMed]

4. Nissim, Y.; Shloberg, M.; Biton, I.; Many, Y.; Doron-Faigenboim, A.; Zemach, H.; Hovav, R.; Kerem, Z.; Avidan, B.; Ben-Ari, G. High temperature environment reduces olive oil yield and quality. PLoS ONE 2020, 15, e231956. [CrossRef] [PubMed]

5. Rojo, J.; Orlandi, F.; Ben Dhiab, A.; Lara, B.; Picornell, A.; Oteros, J.; Msallem, M.; Fornaciari, M.; Pérez-Badia, R. Estimation of chilling and heat accumulation periods based on the timing of olive pollination. Forests 2020, 11, 835. [CrossRef]

6. Nakagawa, M.; Honsho, C.; Kanzaki, S.; Shimizu, K.; Utsunomiya, N. Isolation and expression analysis of FLOWERING LOCUS T-like and gibberellin metabolism genes in biennial-bearing mango trees. Sci. Hortic. 2012, 139, 108-117. [CrossRef]

7. Ding, F.; Zhang, S.; Chen, H.; Su, Z.; Zhang, R.; Xiao, Q.; Li, H. Promoter difference of LcFT1 is a leading cause of natural variation of flowering timing in different litchi cultivars (Litchi chinensis Sonn.). Plant Sci. Int. J. Exp. Plant Biol. 2015, 241, 128-137. [CrossRef] 
8. Haberman, A.; Bakhshian, O.; Cerezo-Medina, S.; Paltiel, J.; Adler, C.; Ben-Ari, G.; Mercado, J.A.; Pliego-Alfaro, F.; Lavee, S.; Samach, A. A possible role for flowering locus T-encoding genes in interpreting environmental and internal cues affecting olive (Olea europaea L.) flower induction. Plant Cell Environ. 2017, 40, 1263-1280. [CrossRef] [PubMed]

9. Hartman, H.T. Effect of winter chilling on fruitfulness and vegetative growth in the olive. Proc. Am. Soc. Hortic. Sci. 1953, 62, 184-190.

10. Rallo, L.; Martin, G.C. The role of chilling in releasing olive floral buds from dormancy. HortScience 1991, 26, 1058-1062. [CrossRef]

11. Andrés, F.; Coupland, G. The genetic basis of flowering responses to seasonal cues. Nat. Rev. Genet. 2012, 13, 627-639. [CrossRef]

12. Samach, A.; Smith, H.M. Constraints to obtaining consistent annual yields in perennials. II: Environment and fruit load affect induction of flowering. Plant Sci. 2013, 207, 168-176. [CrossRef]

13. Périlleux, C.; Bouché, F.; Randoux, M.; Orman-Ligeza, B. Turning meristems into fortresses. Trends Plant Sci. 2019, 24, 431-442. [CrossRef]

14. Hartmann, H.T.; Porlingis, I. Effect of different amounts of winter chilling on fruitfulness of several olive varieties. Bot. Gaz. 1957, 119, 102-104. [CrossRef]

15. Hackett, W.P.; Hartmann, H.T. The influence of temperature on floral initiation in the olive. Physiol. Plant. 1967, 20, 430-436. [CrossRef]

16. Gabaldón-Leal, C.; Ruiz-Ramos, M.; de la Rosa, R.; León, L.; Belaj, A.; Rodríguez, A.; Santos, C.; Lorite, I.J. Impact of changes in mean and extreme temperatures caused by climate change on olive flowering in southern Spain. Int. J. Climatol. 2017, 37, 940-957. [CrossRef]

17. De Melo-Abreu, J.P.; Barranco, D.; Cordeiro, A.M.; Tous, J.; Rogado, B.M.; Villalobos, F.J. Modelling olive flowering date using chilling for dormancy release and thermal time. Agric. For. Meteorol. 2004, 125, 117-127. [CrossRef]

18. Benlloch-González, M.; Sanchez-Lucas, R.; Benlloch, M.; Ricardo, F.-E. An approach to global warming effects on flowering and fruit set of olive trees growing under field conditions. Sci. Hortic. 2018, 240, 405-410. [CrossRef]

19. Medina-Alonso, M.G.; Navas, J.F.; Cabezas, J.M.; Weiland, C.M.; Ríos-Mesa, D.; Lorite, I.J.; León, L.; la Rosa, R.d. Differences on flowering phenology under Mediterranean and Subtropical environments for two representative olive cultivars. Environ. Exp. Bot. 2020, 180, 104239. [CrossRef]

20. Aybar, V.E.; De Melo-Abreu, J.P.; Searles, P.S.; Matias, A.C.; Del Rio, C.; Caballero, J.M.; Rousseaux, M.C. Evaluation of olive flowering at low latitude sites in Argentina using a chilling requirement model. Span. J. Agric. Res. 2015, 13, e0901. [CrossRef]

21. Lorite, I.J.; Gabaldón-Leal, C.; Ruiz-Ramos, M.; Belaj, A.; de la Rosa, R.; León, L.; Santos, C. Evaluation of olive response and adaptation strategies to climate change under semi-arid conditions. Agric. Water Manag. 2018, 204, 247-261. [CrossRef]

22. Saumitou-Laprade, P.; Vernet, P.; Vekemans, X.; Billiard, S.; Gallina, S.; Essalouh, L.; Mhaïs, A.; Moukhli, A.; El Bakkali, A.; Barcaccia, G.; et al. Elucidation of the genetic architecture of self-incompatibility in olive: Evolutionary consequences and perspectives for orchard management. Evol. Appl. 2017, 10, 867-880. [CrossRef]

23. Cuevas, J.; Polito, V.S. The role of staminate flowers in the breeding system of Olea europaea (Oleaceae): An andromonoecious, wind-pollinated taxon. Ann. Bot. 2004, 93, 547-553. [CrossRef] [PubMed]

24. Alagna, F.; Caceres, M.E.; Pandolfi, S.; Collani, S.; Mousavi, S.; Mariotti, R.; Cultrera, N.G.M.; Baldoni, L.; Barcaccia, G. The paradox of self-fertile varieties in the context of self-incompatible genotypes in olive. Front. Plant Sci. 2019, 10, 1-7. [CrossRef] [PubMed]

25. Cruden, R.W. Pollen grains: Why so many? Plant Syst. Evol. 2000, 222, 143-165. [CrossRef]

26. García-Mozo, H.; Comtois, P.; Kuehne, E. Aerobiological Clines: The Role of Topography as a Barrier for Establishing Dispersal Corridors. Aerobiologia 2004, 20, 161-172. [CrossRef]

27. Pinillos, V.; Cuevas, J. Open-pollination provides sufficient levels of cross-pollen in spanish monovarietal olive orchards HortScience 2009, 44, 499-502. [CrossRef]

28. Rojo, J.; Orlandi, F.; Pérez-Badia, R.; Aguilera, F.; Ben Dhiab, A.; Bouziane, H.; Díaz de la Guardia, C.; Galán, C.; Gutiérrez-Bustillo, A.M.; Moreno-Grau, S.; et al. Modeling olive pollen intensity in the Mediterranean region through analysis of emission sources. Sci. Total Environ. 2016, 551-552, 73-82. [CrossRef] [PubMed]

29. Aguilera, F.; Fornaciari, M.; Ruiz-Valenzuela, L.; Galán, C.; Msallem, M.; Dhiab, A.B.; la Guardia, C.D.-d.; del Mar Trigo, M.; Bonofiglio, T.; Orlandi, F. Phenological models to predict the main flowering phases of olive (Olea europaea L.) along a latitudinal and longitudinal gradient across the Mediterranean region. Int. J. Biometeorol. 2015, 59, 629-641. [CrossRef]

30. Orlandi, F.; García-Mozo, H.; Galán, C.; Romano, B.; de la Guardia, C.D.; Ruiz, L.; del Mar Trigo, M.; Dominguez-Vilches, E.; Fornaciari, M. Olive flowering trends in a large Mediterranean area (Italy and Spain). Int. J. Biometeorol. 2010, 54, 151-163. [CrossRef]

31. Osborne, C.P.; Chuine, I.; Viner, D.; Woodward, F.I. Olive phenology as a sensitive indicator of future climatic warming in the Mediterranean. Plant Cell Environ. 2000, 23, 701-710. [CrossRef]

32. Cuevas, J.; Rallo, L.; Rapoport, H. Initial fruit set at high temperature in olive, Olea europaea L. J. Hortic. Sci. 1994, 69, 665-672. [CrossRef]

33. Vuletin Selak, G.; Perica, S.; Goreta Ban, S.; Poljak, M. The effect of temperature and genotype on pollen performance in olive (Olea europaea L.). Sci. Hortic. 2013, 156, 38-46. [CrossRef]

34. Vuletin Selak, G.; Goreta Ban, S.; Perica, S. The effect of temperature on olive pollen germination. Acta Hortic. 2019, 1231, 49-54. [CrossRef] 
35. Koubouris, G.C.; Metzidakis, I.T.; Vasilakakis, M.D. Impact of temperature on olive (Olea europaea L.) pollen performance in relation to relative humidity and genotype. Environ. Exp. Bot. 2009, 67, 209-214. [CrossRef]

36. Wang, X.G.; Johnson, M.W.; Daane, K.M.; Opp, S. Combined effects of heat stress and food supply on flight performance of olive fruit fly (Diptera: Tephritidae). Ann. Entomol. Soc. Am. 2009, 102, 727-734. [CrossRef]

37. Denaxa, N.K.; Roussos, P.A.; Damvakaris, T.; Stournaras, V. Comparative effects of exogenous glycine betaine, kaolin clay particles and Ambiol on photosynthesis, leaf sclerophylly indexes and heat load of olive cv. Chondrolia Chalkidikis under drought. Sci. Hortic. 2012, 137, 87-94. [CrossRef]

38. Markou, M.; Moraiti, C.A.; Stylianou, A.; Papadavid, G. Addressing climate change impacts on agriculture: Adaptation measures for six crops in Cyprus. Atmosphere 2020, 11, 483. [CrossRef]

39. Montes-Osuna, N.; Mercado-Blanco, J. Verticillium wilt of olive and its control: What did we learn during the last decade? Plants 2020, 9, 735. [CrossRef]

40. Alagna, F.; Mariotti, R.; Panara, F.; Caporali, S.; Urbani, S.; Veneziani, G.; Esposto, S.; Taticchi, A.; Rosati, A.; Rao, R.; et al. Olive phenolic compounds: Metabolic and transcriptional profiling during fruit development. BMC Plant Biol. 2012, 12, 162. [CrossRef] [PubMed]

41. Cirilli, M.; Caruso, G.; Gennai, C.; Urbani, S.; Frioni, E.; Ruzzi, M.; Servili, M.; Gucci, R.; Poerio, E.; Muleo, R. The role of polyphenoloxidase, peroxidase, and $\beta$-glucosidase in phenolics accumulation in Olea europaea L. fruits under different water regimes. Front. Plant Sci. 2017, 8, 717. [CrossRef] [PubMed]

42. Gómez-Rico, A.; Salvador, M.D.; La Greca, M.; Fregapane, G. Phenolic and volatile compounds of extra virgin olive oil (Olea europaea L. cv. Cornicabra) with regard to fruit ripening and irrigation management. J. Agric. Food Chem. 2006, 54, 7130-7136. [CrossRef]

43. Servili, M.; Esposto, S.; Lodolini, E.; Selvaggini, R.; Taticchi, A.; Urbani, S.; Montedoro, G.; Serravalle, M.; Gucci, R. Irrigation effects on quality, phenolic composition, and selected volatiles of virgin olive oils cv. Leccino. J. Agric. Food Chem. 2007, 55, 6609-6618. [CrossRef]

44. Tovar, M.J.; Romero, M.P.; Girona, J.; Motilva, M.J. L-Phenylalanine ammonia-lyase activity and concentration of phenolics in developing olive (Olea europaea L cv Arbequina) fruit grown under different irrigation regimes. J. Sci. Food Agric. 2002, 82, 892-898. [CrossRef]

45. Gray, S.B.; Brady, S.M. Plant developmental responses to climate change. Dev. Biol. 2016, 419, 64-77. [CrossRef] [PubMed]

46. Ismail, A.M.; Hall, A.E. Reproductive-stage heat tolerance, leaf membrane thermostability and plant morphology in cowpea. Crop Sci. 1999, 39, 1762-1768. [CrossRef]

47. Vollenweider, P.; Günthardt-Goerg, M.S. Diagnosis of abiotic and biotic stress factors using the visible symptoms in foliage. Environ. Pollut. 2005, 137, 455-465. [CrossRef]

48. Maestri, E.; Klueva, N.; Perrotta, C.; Gulli, M.; Nguyen, H.T.; Marmiroli, N. Molecular genetics of heat tolerance and heat shock proteins in cereals. Plant Mol. Biol. 2002, 48, 667-681. [CrossRef]

49. Wilhelm, E.P.; Mullen, R.E.; Keeling, P.L.; Singletary, G.W. Heat stress during grain filling in maize: Effects on kernel growth and metabolism. Crop Sci. 1999, 39, 1733-1741. [CrossRef]

50. Barnabas, B.; Jager, K.; Feher, A. The effect of drought and heat stress on reproductive processes in cereals. Plant Cell Environ. 2008, 31, 11-38. [CrossRef]

51. Bray, E.A.; Bailey-Serres, J.; Weretilnyk, E. Responses to abiotic stresses. In Biochemistry and Molecular Biology of Plants; Gruissem, W., Jones, R., Eds.; American Society of Plant Physiologists: Rockville, MD, USA, 2000; pp. 1158-1203.

52. Guy, C. Molecular responses of plants to cold shock and cold acclimation. J. Mol. Microbiol. Biotechnol. 1999, 1, $231-242$.

53. Weis, E.; Berry, J.A. Plants and high temperature stress. Symp. Soc. Exp. Biol. 1988, 42, 329-346. [PubMed]

54. Fahad, S.; Bajwa, A.A.; Nazir, U.; Anjum, S.A.; Farooq, A.; Zohaib, A.; Sadia, S.; Nasim, W.; Adkins, S.; Saud, S.; et al. Crop production under drought and heat stress: Plant responses and management options. Front. Plant Sci. 2017, 8, 1147. [CrossRef] [PubMed]

55. Hartmann, H.T. Growth of the olive fruit. Proc. Am. Soc. Hortic. Sci. 1949, 54, 86-94.

56. Lavee, S. Olive. In Handbook of Fruit Set and Development; Monselise, S.P., Ed.; CRC Press: Boca Raton, FL, USA, 1986; pp. 261-276.

57. Rallo, P.; Rapoport, H. Early growth and development of the olive fruit mesocarp. J. Hortic. Sci. Biotechnol. 2001, 76, 408-412. [CrossRef]

58. Hammami, S.B.M.; Manrique, T.; Rapoport, H.F. Cultivar-based fruit size in olive depends on different tissue and cellular processes throughout growth. Sci. Hortic. 2011, 130, 445-451. [CrossRef]

59. García-Inza, G.P.; Castro, D.N.; Hall, A.J.; Rousseaux, M.C. Responses to temperature of fruit dry weight, oil concentration, and oil fatty acid composition in olive (Olea europaea L. var. 'Arauco'). Eur. J. Agron. 2014, 54, 107-115. [CrossRef]

60. Trentacoste, E.R.; Puertas, C.M.; Sadras, V.O. Modelling the intraspecific variation in the dynamics of fruit growth, oil and water concentration in olive (Olea europaea L.). Eur. J. Agron. 2012, 38, 83-93. [CrossRef]

61. Bertin, N. Analysis of the tomato fruit growth response to temperature and plant fruit load in relation to cell division, cell expansion and DNA endoreduplication. Ann. Bot. 2005, 95, 439-447. [CrossRef]

62. Fanwoua, J.; Visser, P.B.; Heuvelink, E.; Angenent, G.; Yin, X.; Marcelis, L.; Struik, P. Response of cell division and cell expansion to local fruit heating in tomato fruit. J. Am. Soc. Hortic. Sci. 2012, 137, 294-301. [CrossRef] 
63. García-Inza, G.P.; Hall, A.J.; Rousseaux, M.C. Proportion of oleic acid in olive oil as influenced by the dimensions of the daily temperature oscillation. Sci. Hortic. 2018, 227, 305-312. [CrossRef]

64. López-Bernal, Á.; Fernandes-Silva, A.A.; Vega, V.A.; Hidalgo, J.C.; León, L.; Testi, L.; Villalobos, F.J. A fruit growth approach to estimate oil content in olives. Eur. J. Agron. 2021, 123, 126206. [CrossRef]

65. Breton, C.; Souyris, I.; Villemur, P.; Berville, A. Oil accumulation kinetic along ripening in four olive cultivars varying for fruit size. OCL 2009, 16, 58-64. [CrossRef]

66. Lavee, S.; Wodner, M. Factors affecting the nature of oil accumulation in fruit of olive (Olea europaea L.) cultivars. J. Hortic. Sci. 1991, 66, 583-591. [CrossRef]

67. Matteucci, M.; D'Angeli, S.; Errico, S.; Lamanna, R.; Perrotta, G.; Altamura, M.M. Cold affects the transcription of fatty acid desaturases and oil quality in the fruit of Olea europaea L. genotypes with different cold hardiness. J. Exp. Bot. 2011, 62, 3403-3420. [CrossRef]

68. Miserere, A.; Searles, P.S.; García-Inza, G.P.; Rousseaux, M.C. Elevated temperature affects vegetative growth and fruit oil concentration in olive trees (Olea europaea). In Proceedings of the VIII International Olive Symposium 1199, Split, Croatia, 10-14 October 2016; pp. 523-528. [CrossRef]

69. van der Merwe, R.; Labuschagne, M.T.; Herselman, L.; Hugo, A. Effect of heat stress on seed yield components and oil composition in high- and mid-oleic sunflower hybrids. S. Afr. J. Plant Soil 2015, 32, 121-128. [CrossRef]

70. Goldman, S. The Effects of Heat Stress on High Oil Corn; Western Kentucky University: Bowling Green, KY, USA, 2005.

71. Rondanini, D.P.; Castro, D.N.; Searles, P.S.; Rousseaux, M.C. Contrasting patterns of fatty acid composition and oil accumulation during fruit growth in several olive varieties and locations in a non-Mediterranean region. Eur. J. Agron. 2014, 52, 237-246. [CrossRef]

72. Nissim, Y.; Shlosberg, M.; Biton, I.; Many, Y.; Doron-Faigenboim, A.; Hovav, R.; Kerem, Z.; Avidan, B.; Ben-Ari, G. A High Temperature Environment Regulates the Olive Oil Biosynthesis Network. Plants 2020, 9, 1135. [CrossRef]

73. Lombardo, N.; Marone, E.; Alessandrino, M.; Godino, G.; Madeo, A.; Fiorino, P. Influence of growing season temperatures in the fatty acids (FAs) of triacilglycerols (TAGs) composition in Italian cultivars of Olea europaea. Adv. Hortic. Sci. 2008, 22, 49-53.

74. Barazani, O.; Keren-Keiserman, A.; Westberg, E.; Hanin, N.; Dag, A.; Ben-Ari, G.; Fragman-Sapir, O.; Tugendhaft, Y.; Kerem, Z.; Kadereit, J.W. Genetic variation of naturally growing olive trees in Israel: From abandoned groves to feral and wild? BMC Plant Biol. 2016, 16, 261. [CrossRef]

75. Available online: https://www.internationaloliveoil.org/wp-content/uploads/2021/07/COI-T15-NC3-REV-16-2021-_ENG.pdf (accessed on 26 July 2021).

76. Alowaiesh, B.; Singh, Z.; Fang, Z.; Kailis, S.G. Harvest time impacts the fatty acid compositions, phenolic compounds and sensory attributes of Frantoio and Manzanilla olive oil. Sci. Hortic. 2018, 234, 74-80. [CrossRef]

77. Mougiou, N.; Trikka, F.; Trantas, E.; Ververidis, F.; Makris, A.; Argiriou, A.; Vlachonasios, K.E. Expression of hydroxytyrosol and oleuropein biosynthetic genes are correlated with metabolite accumulation during fruit development in olive, Olea europaea, cv. Koroneiki. Plant Physiol. Biochem. 2018, 128, 41-49. [CrossRef]

78. Dag, A.; Ben-Gal, A.; Yermiyahu, U.; Basheer, L.; Nir, Y.; Kerem, Z. The effect of irrigation level and harvest mechanization on virgin olive oil quality in a traditional rain-fed 'Souri' olive orchard converted to irrigation. J. Sci. Food Agric. 2008, 88, 1524-1528. [CrossRef]

79. Dag, A.; Naor, A.; Ben-Gal, A.; Harlev, G.; Zipori, I.; Schneider, D.; Birger, R.; Peres, M.; Gal, Y.; Kerem, Z. The effect of water stress on super-high-density 'Koroneiki' olive oil quality. J. Sci. Food Agric. 2015, 95, 2016-2020. [CrossRef]

80. Mailer, R.J.; Ayton, J.; Graham, K. The influence of growing region, cultivar and harvest timing on the diversity of Australian olive oil. J. Am. Oil Chem. Soc. 2010, 87, 877-884. [CrossRef]

81. Hernández, M.L.; Padilla, M.N.; Sicardo, M.D.; Mancha, M.; Martínez-Rivas, J.M. Effect of different environmental stresses on the expression of oleate desaturase genes and fatty acid composition in olive fruit. Phytochemistry 2011, 72, 178-187. [CrossRef]

82. Tamborrino, A.; Romaniello, R.; Caponio, F.; Squeo, G.; Leone, A. Combined industrial olive oil extraction plant using ultrasounds, microwave, and heat exchange: Impact on olive oil quality and yield. J. Food Eng. 2019, 245, 124-130. [CrossRef]

83. Conte, L.; Milani, A.; Calligaris, S.; Rovellini, P.; Lucci, P.; Nicoli, M.C. Temperature dependence of oxidation kinetics of extra virgin olive oil (EVOO) and shelf-life prediction. Foods 2020, 9, 295. [CrossRef]

84. Diamantakos, P.; Giannara, T.; Skarkou, M.; Melliou, E.; Magiatis, P. Influence of harvest time and malaxation conditions on the concentration of individual phenols in extra virgin olive oil related to its healthy properties. Molecules 2020, 25, 2449. [CrossRef] [PubMed]

85. Skodra, C.; Titeli, V.S.; Michailidis, M.; Bazakos, C.; Ganopoulos, I.; Molassiotis, A.; Tanou, G. Olive Fruit Development and Ripening: Break on through to the "-Omics" Side. Int. J. Mol. Sci. 2021, 22, 5806. [CrossRef] [PubMed]

86. Ramli, U.S.; Othman, A.; Tahir, N.I.M.; Lau, B.Y.C.; Shahwan, S.; Hassan, H.; Nurazah, Z.; Dzulkafli, S.B.; Rozali, N.L.; Ishak, N.A.; et al. Omics-A potential tool for oil palm improvement and productivity. In The Oil Palm Genome; Springer: Cham, Switzerland, 2020; pp. 141-157. [CrossRef]

87. Paradiso, V.M.; Pasqualone, A.; Summo, C.; Caponio, F. An "omics" approach for lipid oxidation in foods: The case of free fatty acids in bulk purified olive oil. Eur. J. Lipid Sci. Technol. 2018, 120, 1800102. [CrossRef]

88. Piroddi, M.; Albini, A.; Fabiani, R.; Giovannelli, L.; Luceri, C.; Natella, F.; Rosignoli, P.; Rossi, T.; Taticchi, A.; Servili, M.; et al. Nutrigenomics of extra-virgin olive oil: A review. BioFactors 2017, 43, 17-41. [CrossRef] [PubMed] 
89. Caruso, G.; Rapoport, H.F.; Gucci, R. Long-term evaluation of yield components of young olive trees during the onset of fruit production under different irrigation regimes. Irrig. Sci. 2013, 31, 37-47. [CrossRef]

90. Ozturk, T.; Ceber, Z.P.; Türkeş, M.; Kurnaz, M.L. Projections of climate change in the Mediterranean Basin by using downscaled global climate model outputs. Int. J. Climatol. 2015, 35, 4276-4292. [CrossRef] 